\title{
THE FUTURE OF THE EXPLOITATION OF THE RESOURCES OF THE DEEP SEABED AND SUBSOIL*
}

\author{
JOHN S. BAILEY† \\ I \\ INTRODUCTION
}

My paper offers some thoughts in crystal-ball gazing about the future of seabed mining from an economic, political, and legal point of view.

The present economic environment does not augur well for deep seabed mining. World demand for the metals is low and prices are depressed. Many landbased mines have shut down. Evaluations of the economics of the industry based on the succession of models from the 1976 Massachusetts Institute of Technology model to the 1982 Texas University model have progressed from guarded optimism to unrestrained pessimism. Yet prosperity, in conjunction with improved metal prices in an era of stability and confidence, could rapidly change the economic future of ocean mining. So could other factors such as lower-cost equipment, higher content of metal in nodules discovered, increased mining and processing efficiency, and a corresponding reduction of capital and operating costs.

Seabed mining could therefore eventually become a more attractive investment. However, as long as land-based supplies of nickel, copper, cobalt, and manganese remain plentiful, it is unlikely that seabed extraction of those metals could be carried out as cheaply or as efficiently. But the date of commencement of seabed mining will depend as much on the desires of certain countries to have what they regard as potentially more assured access to strategic metals and on pressure from developing countries to set in motion the Enterprise, a company established by the Law of the Sea Convention' to conduct ocean mining activities.

Now let us look to the political and legal environment within which seabed mining might develop. I am confident that when deep seabed mining begins it will take place under the regime established by the LOS Convention. One purpose of the Convention is to establish a regime for deep seabed resources that can grant exploitation rights which will be recognized by most, if not all, of the world.

When the LOS Convention comes into force, it will establish an International

\footnotetext{
Copyright (C) 1983 by Law and Contemporary Problems

* This paper represents the personal views of the author and should not be taken as necessarily reflecting the views of the Australian Government.

$\dagger$ Deputy High Commissioner of Australia to Canada; Special Representative of Australia to the Third United Nations Conference on the Law on the Sea; Rapporteur of the First Committee of the Conference.

1. Convention on the Law of the Sea, opened for signalure Dec. 10, 1982, U.N. Doc. A/CONF. 62/122 reprinted in 21 I.L.M. 1261 (1982).
} 
Seabed Authority. The Authority will have the power to issue to private or statecontrolled entities mining rights that will be exclusive against all other miners who satisfy, or are nationals of countries that ratify, the Convention. The Convention will also establish a company, to be called the Enterprise, that will conduct ocean mining activities for the benefit of developing countries. This dual system of access for private miners and for the Enterprise, referred to as the "parallel system," forms the basic compromise between the industrialized and developing countries at the LOS Conference.

II

\section{Mining Outside the Convention}

Some of those who have ideological objections to the legal regime established by the Convention have argued that as the high seas are res communis under international law, companies should exploit the deep seabed under domestic legislation. Aside from the fact that the legal premise of this argument is disputed by most of the world community, pursuing such a course of action has certain practical disadvantages. The possibility of disputes over exclusive rights to a mine site, the lack of agreed provisions for the resolution of such conflicts, and the threat of international legal action by parties to the LOS Convention combine with extremely large capital investment requirements and a long pay-back period to make ocean mining under domestic law extremely unattractive.

In order to overcome the unattractiveness of mining under domestic legislation, certain critics of the Convention have argued in favor of establishing a minitreaty for seabed exploitation. To be really effective, such a treaty would need to include all potential ocean-mining countries (the United States, the United Kingdom, the Federal Republic of Germany, France, Japan, Netherlands, Belgium, Italy, Canada, the USSR, and India) as well as a sufficient number of small industrialized countries and developing states to weaken the support for the Convention. Participation by fewer countries would leave sufficient opportunity for conflict, delay, and harassment by parties outside the minitreaty such that banks and large corporations would find the risks too high to justify the investments required for commercial-scale operations. Recent attempts to establish a minitreaty have not been successful. Not one single industrialized country has been willing to go along with the United States in contravention of the terms of the LOS Convention, even before it was signed.

As Ambassador Malone has revealed, ${ }^{2}$ an attempt to persuade the major industrialized countries not to sign the Convention is at present being undertaken by a United States mission headed by Donald Rumsfeld. It is my firm belief, however, that most industrialized countries will sign and eventually ratify the Convention along with developing countries. The advantages of the nonseabed provisions far outweigh any apparent disadvantages of the seabed provisions. In my opinion any country which is a party to the Convention is prohibited by Article 137(3) from

2. See Malone, The United States and the Law of the Seo After UNCLOS III, LAW \& CONTEMP. PROBS., Spring, 1983, at 29. Ambassador Malone served as chairman of the U.S. delegation to UNCLOS III. 
recognizing mine site claims of a nonparty to the Convention. Even the recently concluded conflict resolution agreement between the United States, the Federal Republic of Germany, the United Kingdom, and France could be short-lived because settlement of overlapping claims implies a recognition by the parties of each others' claims, and it will be ultimately impossible for the Federal Republic of Germany, the United Kingdom, and France to recognize the United States' claims if they sign and eventually ratify the LOS Convention. Most industrialized countries, with the exception of the United States, will next year begin participating in the Preparatory Commission to set up the "rules of the game." This offers a unique opportunity for the commercial competitors of the United States to develop rules of access to one of the world's potentially greatest resources of strategic minerals without necessarily having to take into account the United States' concerns and interests. It is very saddening to me that the United States, with all its fine traditions and experience in international lawmaking, will be absent from the important work of the Preparatory Commission.

Even in the absence of a minitreaty, it is within the capacity of a fertile mind to contemplate the United States "going it alone"-instituting a program of government-backed political risk insurance to eliminate the risks to investment in ocean mining and in other activities in foreign countries. This would, of course, require the United States government to abandon those very same free-market principles to which it subordinated the advantages of joining the Convention. In addition, the United States government would have to ensure that investors would not suffer due to conflicts over mine sites claims by Convention operators. In the event of a conflict of claims between an operator operating under United States domestic law and another operator operating under the Convention, it would be little use for the United States to go to the International Court of Justice on behalf of its operator because it would seem clear that the court would back the operator operating under the Convention. Short of the costly and desperate alternative of employing its Navy to protect the operator on a continuing basis, thus risking armed conflict with its traditional allies, the United States could become embroiled in a sanctions game against European and Japanese companies which would make the recent gas pipeline dispute look like a sparring match. I can only hope that those of us who are aghast at the thought of such a scenario and who value the United States becoming a party to the Convention will work at the Preparatory Commission towards developing rules and regulations attractive enough to induce a future U.S. administration and Senate to agree to the United States becoming a party.

\section{III}

\section{The Parallel System}

If seabed mining is to take place under the legal regime set up by the LOS Convention, it is appropriate to ask whether this regime will encourage or discourage seabed mining. One has to look at this from the two sides of the parallel system-the Enterprise on the one hand and states and companies on the other.

As far as the Enterprise is concerned, the prospects would seem quite rosy. It will have prospected sites offered to it upon which considerable research and devel- 
opment have been expended. It could have as startup capital as much as half the cost of an integrated mining, transportation, and processing project as well as guaranteed loans for the same amount. If the United States were not to become a party to the Convention, the total funds available to the Enterprise would be reduced by approximately one quarter. It would still be left with a tidy sum to commence mining operations on at least two sites, having purchased the technology to do the same, or to go into a joint venture in an integrated project with a state or company from the other side of the parallel system. In addition, it will have priority with respect to being granted production authorization. The only problem is that the Enterprise will not get its site until a license is granted to an entity on the other side of the parallel system. However, with the political pressure to get the Enterprise functioning at an early stage, the directors of the Enterprise will at least in the initial stages be doing their utmost to encourage activities on the other side of the parallel system.

As far as the corporation working on the other side of the parallel is concerned, the Convention offers widely-accepted exploitation rights and orderly resolution of conflicting claims, thus facilitating planning and capital-raising activities. Furthermore, as the terms of the contract are written into the Convention itself, the miner will not be faced with the prospect of forced renegotiation or expropriation that he sometimes finds with his land-based activities today.

There are of course some provisions in the Convention that do impose financial burdens and have elements of uncertainty in their application. But $I$ agree with the views of two United States authors" in a recent article entitled "Incentives for Ocean Mining under the New Law of the Sea." 4 These authors, who incidentally have been longstanding members of the U.S. LOS delegations, argue forcefully that the disincentives to seabed mining are more apparent than real and from a commercial point of view might not warrant the political controversy that has been caused from leaving these provisions in the Convention. This is particularly so given the mitigating effects of a resolution on protection of pioneer investment to which I shall refer below.

The authors point out that even the practical effects of the most controversial provisions for the sale of technology from the private miner to the Enterprise and to developing states would entail little cost to the miner. The authors cite a number of reasons for this, the principal one being that the sale of technology may be required only if such technology is not available on the open market. A recent contract study by the U.S. Department of the Interior indicates that there are at least four suppliers for every component of an ocean mining system and for the design and construction of the system itself. ${ }^{5}$

Much has been said about the magnitude of payments made under the Con-

3. Lance N. Antrim, Office of Technology Assessment, U.S. Congress; James K. Sebenius, Harvard University.

4. Antrim \& Sebenius, Incentives for Ocean Mining Under the Neu Law of the Sea, in LAW (OF THE SEA: U.S. POlicy DilemMa $79-99$ (1983).

5. Science Applications, Inc., Alternatives for Technology Transrer to the Enterprise 61 (1978) (available from National Technical Information Service, Springfield, Va.). 
vention, but these are favorably comparable with payments made to developing countries by investors in land-based mining operations. While the payments will be substantial, they can be borne by investors in part because of the progressive tax system established by the Convention. As one of those associated with its drafting, I would like to think of the system as one of the most sophisticated and flexible mining tax systems in the world today. In addition, the financial burden on investors could be substantially reduced if the investor's parent government allowed all or part of the profit-sharing payments to be credited against its taxes in the same manner as is common with land-based mining. Alternatively, there are double taxing agreements of the type which many industrialized countries, including the United States, have entered into with developing countries. As these industrialized countries have agreed, in return for assured access to seabed minerals, to a system by which the Authority has taxing powers, there is nothing inconsistent with their entering into double-taxing arrangements with the Authority.

While many disincentives contained in the provisions are more apparent than real, much can be done by the Preparatory Commission to clarify definitions and terms and remove uncertainties that can go a long way towards stimulating investor confidence in seabed mining.

One of the breakthroughs from the private investors' point of view was the adoption by the LOS Conference of Resolution II, the Protection of Pioneer Investors. The purpose of the resolution was to provide the stability and certainty necessary to encourage continuation of development activities already underway. This resolution attempts to reduce investor uncertainty through the recognition of the exclusive right to explore a mine site and the assurance of a contract to exploit the mine site once the Convention comes into force.

The four multinational consortia which may register as pioneer investors have partners which are incorporated in the United States. Were the United States to remain outside the Convention, it would be necessary for the consortia, if they were registered as pioneer investors, either to incorporate themselves outside the United States or else ensure that their U.S. partners changed their places of incorporation if they were to receive licenses to exploit their mine sites.

\section{IV}

\section{JOINT VENTURES}

We have examined the scenario from both sides of the parallel system. However, seabed mining under the Convention must be looked at in its totality with the parallel system as an interdependent one. I have always regarded the parallel system with the Kissinger proposals for the financing of the Enterprise and the transfer of technology thereto as an ingenious political compromise-a theoretical system that nearly everyone playing the negotiating game was aware might easily not turn out quite that way in practice. Fortunately, enough flexibility was allowed in the system to permit each side of the system, states and nationals on the one hand and the Enterprise on the other, having obtained rights to work their 
sites individually, to go into joint ventures. I am convinced that future seabed mining under the Convention will be predominantly, by joint-venture activity.

In forming joint ventures, private firms may avail themselves of some of the advantages of the Enterprise. The terms of the joint venture would be established by negotiation between the Enterprise and the private firm; but, since there is always the opportunity to mine under the private system, the terms of the joint venture must improve on the provisions relating to the parallel system.

There are a number of reasons for the Enterprise to be interested in forming joint ventures, particularly in the early years under the Convention. I list a few:

(i) political pressure for the Enterprise to begin mining at the same time as the first miner in the nonrestricted area;

(ii) reduction of the risk of loss of the only investment capital available to the Enterprise by spreading the risk over several joint ventures with experienced mining companies; and

(iii) ability to begin operations without a large body of trained personnel.

Private firms will have a number of incentives to choose joint ventures rather than operate on the private side of the system (and indeed, rather than operate outside the Convention regime). These include:

(i) access to the investment capital of the Enterprise which, even without United States contributions, would probably approach $\$ 1$ billion;

(ii) opportunity to negotiate reduced financial payments to the Authority;

(iii) assurance of the approval of plans of work for the conduct of exploration and exploitation activities; and

(iv) avoidance of the technology transfer provisions of the private access system.

\section{V \\ CONClusion}

In conclusion, therefore, my predictions are that despite the readily available, abundant, land-based supplies of nickel, copper, cobalt and manganese at present, seabed mining for political and strategic reasons alone will get underway when world economic conditions are favorable. The only workable legal regime governing seabed mining activities will be that laid down in the LOS Convention and the rules and regulations of the International Seabed Authority drawn up by the Preparatory Commission. Any industrialized country with a strategic need for deep-ocean minerals that remains outside the Convention will do so at the risk of losing assured and direct access to those minerals. 